\title{
Perkecambahan Peronosclerospora spp. Asal Beberapa Daerah di Jawa Barat pada Fungisida Berbahan Aktif Metalaksil, Dimetomorf dan Fenamidon
}

\author{
Fitri Widiantini ${ }^{1}$, Dwisari Januarily Pitaloka ${ }^{2}$, Ceppy Nasahi ${ }^{1}$, dan Endah Yulia ${ }^{1}$ \\ ${ }^{1}$ Departemen Hama dan Penyakit Tumbuhan Fakultas Pertanian Universitas Padjadjaran \\ Jl. Raya Bandung Sumedang Km 21 Jatinangor Jawa Barat 45363 \\ ${ }^{2}$ Alumni Program Studi Agroteknologi Fakultas Pertanian Universitas Padjadjaran \\ Jl. Raya Bandung Sumedang Km 21 Jatinangor Jawa Barat 45363 \\ *Alamat Korespondensi: fitri.widiantini@unpad.ac.id
}

\begin{abstract}
Germination of Peronosclerospora spp. isolated from several maize plantation areas in West Java on fungicides containing active ingredient of metalaxyl, dimetomorph and fenamidone
\end{abstract}

Downy mildew is a major disease in corn plants that affect the world corn production, include in Indonesia. The control of downy mildew that caused by pathogen Peronosclerospora spp. are relying on the use of synthetic fungicides. However, the emergence of the Peronosclerospora spp. resistant against fungicides rise awareness for the need of constant surveillance. The aim of this study was to know the effectiveness of three commonly used active ingredients fungicide (Metalaxyl, Dimetomorph, and Fenamidone) in controlling Peronosclerospora spp. from five regions in Wes Java (Sumedang District,Bandung District, Majalengka District, Garut District and West Bandung District). Experiment was conducted using conidia germination method. The results of this study demonstrated that fungicide with active ingredient of Dimethomorph was able to suppress the germination of conidia Peronosclerospora spp. with $0 \%$ of conidia germination in 4 districts (Sumedang, Bandung, Majalengka and Garut) and only $0.47 \%$ conidia germinated in isolate collected from West Bandung District. Meanwhile, fenamidon experienced a decrease in effectiveness at West Bandung District. In this study, it was also found that the number of conidia germinated on isolates treated with Metalaxyl did not show any significant difference compared to control. This suggested that Peronosclerospora spp. might resistant to Metalaxyl.

Keywords: Downy mildew, Peronosclerospora spp., metalaxyl, dimetomorph, fenamidone

\section{ABSTRAK}

Penyakit bulai merupakan penyakit utama pada tanaman jagung yang berpengaruh terhadap produksi jagung dunia, termasuk di Indonesia. Pengendalian penyakit bulai yang disebabkan oleh patogen Peronosclerospora spp. masih bertumpu pada penggunaan fungisida sintetik. Akan tetapi, terjadinya penurunan keefektifan fungisida terhadap Peronosclerospora spp. menyebbkan diperlukannya monitoring secara berkala. Penelitian ini bertujuan untuk mengetahui keefektifan tiga jenis bahan aktif fungisida yang umum digunakan (Metalaksil, Dimetomorf, dan Fenamidon) dalam mengendalikan penyakit bulai terhadap patogen Peronosclerospora spp.asal lima daerah di Jawa Barat (Kab. Sumedang, Kab. Bandung, Kab. Majalengka, Kab. Garut dan Kab. Bandung Barat). Pengujian keefektifan fungisida dilakukan dengan menggunakan metode perkecambahan konidia. Hasil penelitian menunjukkan bahwa perlakuan fungsida dimetomorf terhadap isolat Peronosclerospora spp. asal semua daerah dapat menekan perkecambahan konidia dengan persentase perkecambahannya $0 \%$ pada 4 daerah dan $0,47 \%$ pada isolat asal daerah Kab. Bandung Barat. Sementara Fenamidon menujukkan indikasi penurunan keefektifan di daerah Bandung Barat. Pada penelitian ini, ditemukan pula adanya indikasi resistensi patogen Peronosclerospora spp. terhadap fungisida Metalaksil. Hal ini terlihat dari perkecambahan konidia yang diperlakukan 
dengan Metalaksil yang hasilnya tidak berbeda nyata dengan kontrol yang tidak diperlakukan dengan fungisida.

Kata Kunci: Penyakit bulai jagung, Peronosclerospora spp., Metalaksil, Dimetomorf, Fenamidon

\section{PENDAHULUAN}

Penyakit bulai pada tanaman jagung yang disebabkan oleh oomycete patogen Peronosclerospora spp. merupakan salah satu faktor penghambat produktivitas jagung yang penting. Penyakit bulai dapat menyebabkan kehilangan hasil produksi tanaman jagung sebanyak 30\% (Rashid et al., 2013), sementara pada tanaman jagung yang rentan kehilangan hasil akibat serangan penyakit bulai dapat mencapai 100\% (Talanca et al., 2011). Penyakit bulai pada beberapa daerah sentra tanaman jagung di Indonesia telah menjadi endemik, seperti yang terjadi di Desa Plemahan, Kecamatan Langenharjo, Kabupaten Kediri dengan intensitas serangan sebesar 95\%, serta Kecamatan Kademangan, Kabupaten Blitar dengan intensitas serangan $60-80 \%$, sehingga penyakit bulai begitu mengancam areal tanaman jagung (Talanca, 2013). Terdapat beberapa faktor yang menyebabkan terjadinya epidemik penyakit pada suatu daerah. Diantaranya penanaman varietas jagung yang rentan terhadap bulai, keefektifan fungisida yang rendah karena adanya pemalsuan ataupun penggunaan dosis yang tidak tepat dan tidak dilakukannya eradikasi terhadap tanaman yang terinfeksi (Burhanuddin, 2009).

Pengendalian penyakit tanaman yang dianggap paling efektif adalah dengan menggunakan tanaman varietas tahan. Akan tetapi keterbatasan tersedianya tanaman tahan penyakit dan sifat ketahanannya yang relatif mudah untuk dipatahkan menyebabkan pengendalian penyakit tanaman masih mengandalkan pada penggunaan fungsida (Agrios, 2005). Dilaporkan oleh McGrath (2004) bahwa fungisida memegang peranan penting dalam pengendalian penyakit tanaman. Aktar et al. (2009) menyebutkan bahwa kerugian secara ekonomi yang cukup besar dapat dialami ketika fungisida tidak digunakan dalam kegiatan budidaya tanaman.

Fungisida sistemik atau fungisida translaminar banyak digunakan untuk mengendalikan penyakit bulai (McGrath, 2001). Setidaknya terdapat empat golongan fungisida yang umum digunakan untuk mengendalikan penyakit bulai, yaitu quinone outside inhibitors (QoI, seperti azoksistrobin, famoksadon dan fenamidon), fenilamid (seperti mefenoxam), carboxylic acid amides (misalnya dimetomorf), dan cyanoacetamidoximes (seperti cymoxanil) (Gisi \& Sierotzki, 2008). Fungisida sistemik merupakan fungisida yang mempunyai target aktivitas yang spesifik sehingga memiliki keefektifan yang tinggi terhadap organisme sasaran. Hal ini berarti fungisida tersebut memiliki resiko toksisitas yang rendah teradap kesehatan manusia dan organisme lainnya. Akan tetapi, hal tersebut juga berarti resiko terbetuknya populasi patogen yang resisten terhadap fungisida menjadi tinggi (McGrath, 2004). Kemunculan strain patogen resisten terhadap fungisida telah terdeteksi sejak awal tahun 1970an (Ishii, 2006).

Populasi patogen yang resisten terhadap fungisida terbentuk melalui dua fase, fase kemunculan dan fase seleksi. Patogen strain resisten muncul karena adanya mutasi yang terbentuk setelah aplikasi fungisida terus menerus. Pada fase kemunculan ini, jumlah strain patogen resisten masih rendah dan dapat dihilangkan melalui introduksi fungisida berbahan aktif yang beda cara kerja dengan fungisida sebelumnya. Akan tetapi, jika aplikasi fungisida baru tidak dilaksanakan, maka jumlah populasi strain patogen resisten akan terus bertambah sehingga memasuki fase seleksi. Pada fase ini aplikasi fungisida akan menambah jumlah populasi patogen yang resisten (Hobbelen et al., 2014). Resistensi patogen terdeteksi melalui penurunan keefektifan fungisida di lapangan, serta perubahan respon patogen baik pertumbuhan koloni maupun perkecambahan patogen secara in vitro (Secor \& Rivera, 2012).

Peronosclerospora spp. dilaporkan telah terdeteksi membentuk populasi yang resisten terhadap fungisida. Ledakan penyakit bulai pada tanaman gandum dilaporkan terjadi di Texas yang diakibatkan dari penggunaan fungisida metalaksil secara terus-menerus (Perumal et al., 2008). Patogen penyebab penyakit bulai pada jagung di Indonesia juga telah dilaporkan menurun sensitivitasnya terhadap fungisida metalaksil. Beberapa laporan menyebutkan penggunaan fungisida metalaksil dalam dosis yang tinggi tidak dapat menurunkan tingkat serangan Peronosclerospora spp. (Burhanuddin, 2009, Talanca et al., 2011). Penelitian ini bertujuan untuk mengetahui resistensi patogen 
penyebab penyakit bulai pada jagung (Peronoscleropsora spp.) yang diisolasi dari beberapa lokasi sentra pertanaman jagung di Jawa Barat melalui respon perkecambahannya.

\section{BAHAN DAN METODE}

\section{Pengumpulan Patogen Penyebab Penyakit Bulai}

Tanaman jagung yang terserang penyakit bulai dikumpulkan dari berbagai pertanaman jagung di beberapa lokasi yang meliputi Kabupaten Sumedang, Kabupaten Bandung, Kabupaten Majalengka, Kabupaten Garut dan Kabupaten Bandung Barat. Tanaman yang menunjukkan gejala bulai dipicu sporulasinya dengan mengikuti metode yang dikembangkan oleh Burhanuddin (2009).

Daun tanaman jagung yang memperlihatkan gejala terserang bulai dipetik dari pangkalnya kemudian dimasukkan dalam plastik yang dilengkapi dengan kertas tissue yang dilembabkan sampai proses selanjutnya. Sampel tersebut kemudian dicuci bersih dengan air mengalir dan dikeringanginkan. Pangkal daun kemudian direndam dalam larutan sukrosa $2 \%$ hingga setinggi $2 \mathrm{~cm}$ dan didiamkan selama 6 jam. Setelah itu daun diinkubasikan semalam dalam plastik yang berisi kertas tissue yang dilembabkan dan diletakkan di luar ruangan pada udara terbuka. Menjelang dini hari, daun jagung dikelurkan dari dalam plastik. Konidia yang terbentuk kemudian dipanen dan dimasukkan ke dalam akuades steril dengan menggunakan kuas halus.

\section{Karakteristik Morfologi Patogen Penyebab Penyakit Bulai}

Konidia Peronosclerospora spp. yang melekat pada daun akan tampak seperti tepung berwarna putih pada permukan daun. Kemudian konidia diambil dengan menggunakan potongan selotip secara perlahan yang kemudian diletakan pada object glass yang telah diberi satu tetes larutan pewarna (Methylene Blue 2\%).

Pada pinggiran selotip di semua sisi diberi kuteks berwarna bening dengan tujuan agar preparat dapat disimpan dalam jangka waktu yang lama. Pengamatan morfologi (bentuk dan ukuran (pxl)) dilakukan pada konidia dan konidiofor yang diamati secara acak. Kemudian dilakukan pengamatan di bawah mikroskop (Sahlan \& Ahmad, 2003).

\section{Perkecambahan Konidia Berbagai Isolat Peronosclerospora spp. terhadap Berbagai Jenis Bahan Aktif Fungisida}

Fungisida dilarutkan dalam akuades steril sesuai dengan anjuran konsentrasi penggunaan masing-masing fungisida yaitu 2 g/l. Fungisida yang telah bercampur dengan akuades di dalam tabung reaksi lalu dihomogenkan menggunakan vortex. Kemudian, sebanyak $50 \mu \mathrm{l}$ Peronosclerospora spp. (kerapatan $10^{4}$ konidia/ml) dicampurkan dengan 50 $\mu$ fungisida pada object glass dan ditutup dengan cover glass. Object glass kemudian disimpan pada wadah tertutup yang telah diberi kertas tissue lembab dan disimpan selama 24 jam. Inkubasi dilakukan dalam kondisi gelap (Secor \& Rivera, 2012). Pengamatan yang dilakukan yaitu dengan menghitung jumlah konidia keseluruhan dan jumlah yang berkecambah yang diamati di bawah mikroskop binokuler dengan perbesaran 40x. Persentase konidia yang berkecambah dihitung dengan menggunakan rumus sebagai berikut (Jatnika dkk., 2013):

Perkecambahan konidia (\%)

$$
=\frac{\text { konidia berkecambah }}{\text { total konidia yang diamati }} \times 100 \%
$$

\section{HASIL DAN PEMBAHASAN}

Identifikasi patogen penyebab penyakit bulai di beberapa lokasi pertanaman jagung di Jawa Barat berdasarkan morfologi konidia dan kondiofornya menunjukkan hasil bahwa $P$. maydis merupakan penyebab penyakit bulai di 4 Kabupatan yaitu Kabupaten Sumedang, Kabupaten Bandung, Kabupaten Majelengka dan Kabupaten Garut (Tabel 1). Sementara penyebab penyakit bulai di Kabupaten Bandung Barat secara morfologi teridentifikasi sebagai $P$. sorghi yang ditunjukkan dengan adanya dinding sel pada konidia yang lebih tebal dibandingkan konidia-konidia yang ditemukan di empat kabupaten lainnya.

Penyebab penyakit bulai di Indonesia diketahui disebabkan oleh tiga spesies, yaitu $P$. maydis, $P$. philliphinensis dan $P$. sorghi (Burhanuddin, 2011). Lebih lanjut dilaporkan pula oleh Burhanuddin (2011), bahwa P. maydis merupakan penyebab bulai di Pulau Jawa sementara penyakit bulai di Sulawesi disebabkan oleh $P$. phillipinensis dan $P$. sorghi merupakan penyabab bulai di Sumatera. 
Tabel 1. Identifikasi spesies penyebab penyakit bulai asal Jawa Barat dilihat dari karakteristik morfologi.

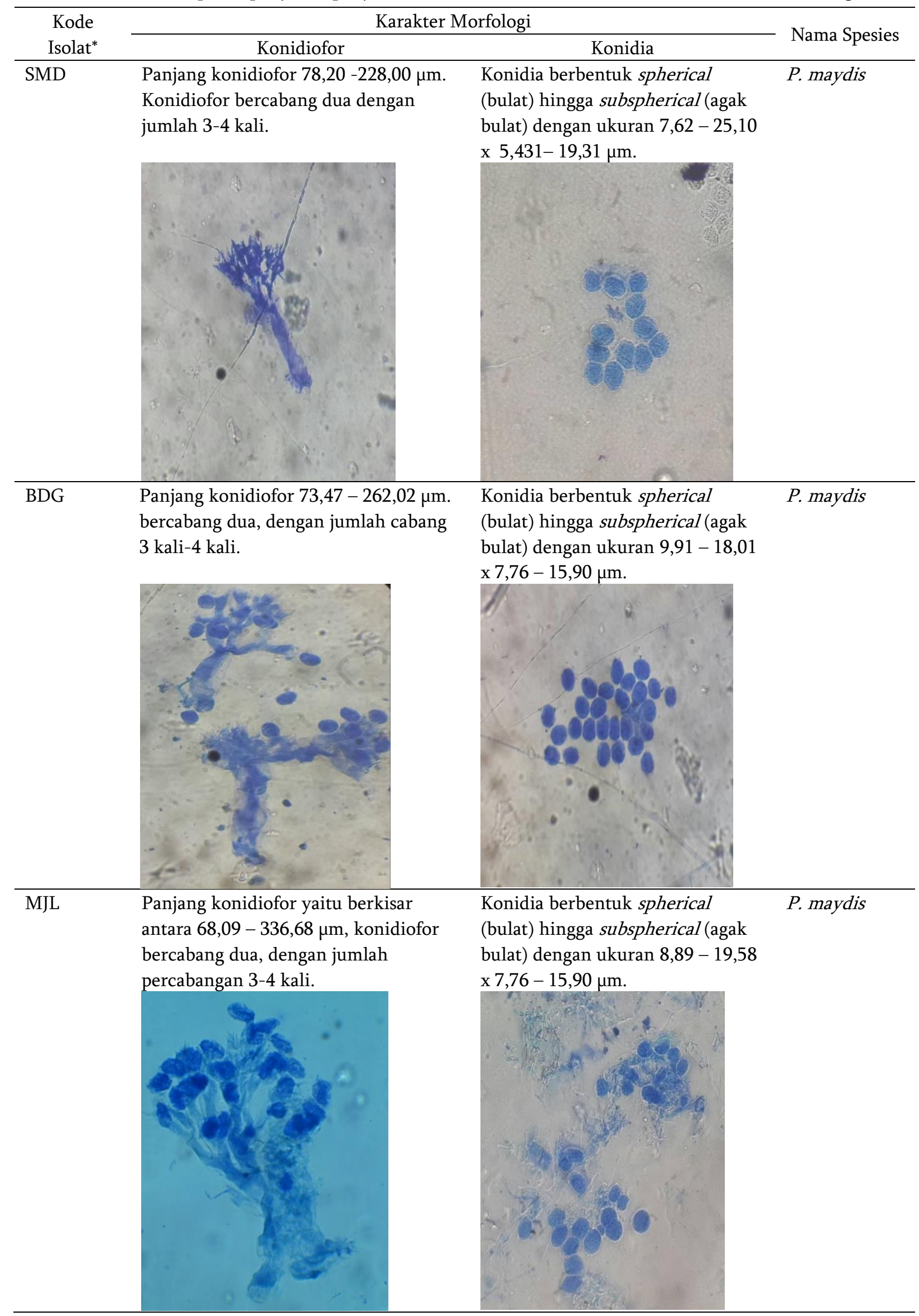


Tabel 4. Identifikasi spesies penyebab penyakit bulai asal Jawa Barat dilihat dari karakteristik morfologi (lanjutan).

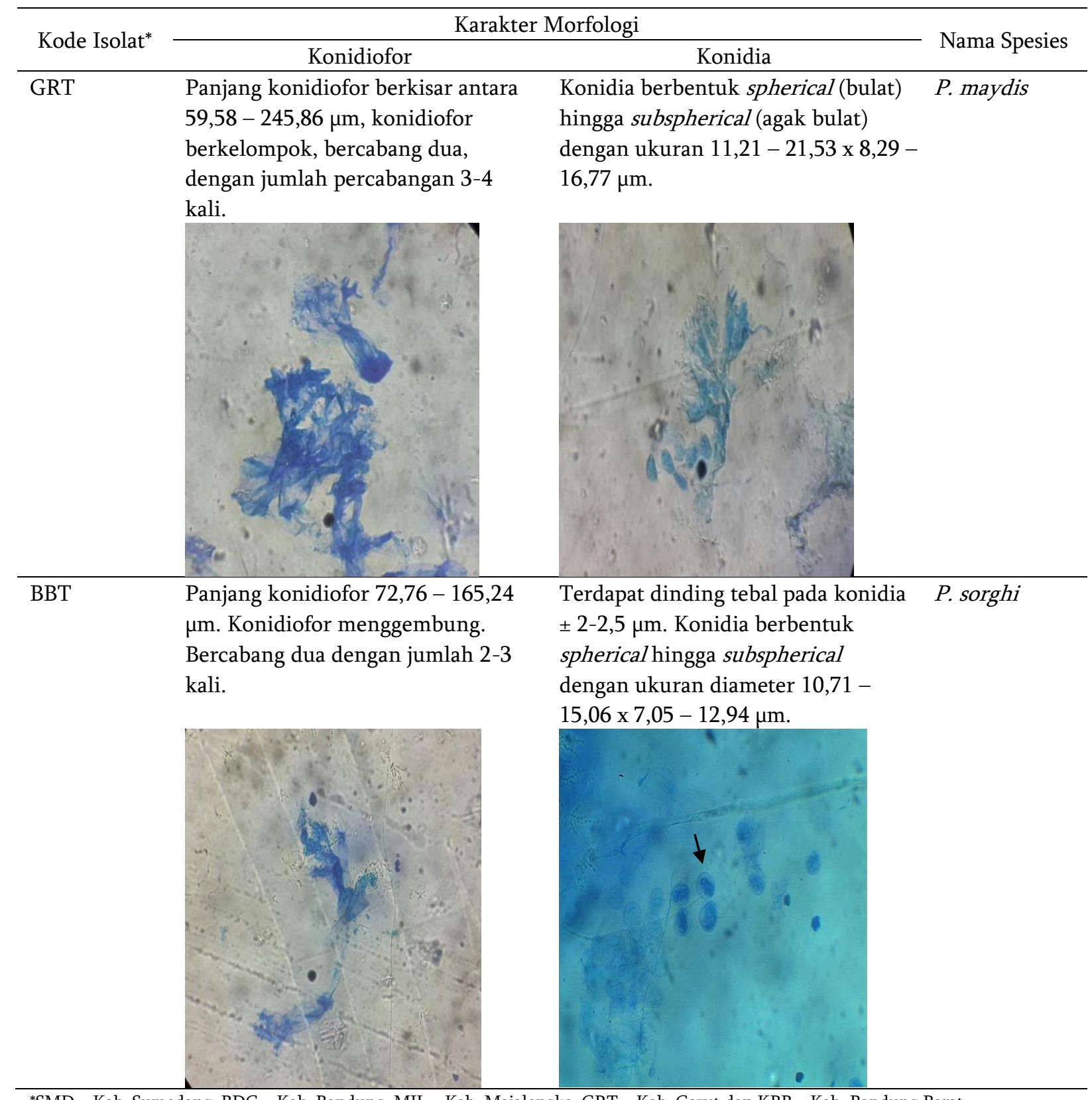

${ }^{*} \mathrm{SMD}=$ Kab. Sumedang, BDG = Kab. Bandung, MJL = Kab. Majalengka, GRT = Kab. Garut dan KBB = Kab. Bandung Barat.

Akan tetapi dalam beberapa waktu dekat ini beberapa laporan menunjukkan bahwa $P$. sorghi ditemukan pula di daerah Bogor Jawa Barat (Rustini et al., 2015) dan P. maydis ditemukan di Lampung (Muis, 2012). Hal tersebut menunjukkan adanya penyebaran patogen penyebab penyakit bulai dari satu daerah ke daerah lainnya. Konidia Peronosclerospora spp. umumnya terbentuk menjelang dini hari (Burhanuddin, 2011). Setelah konidia terbentuk, konidia terlepas dan menyebar ke daerah sekitar dengan bantuan angin. Konidia dapat menginfeksi tanaman jagung yang jaraknya berkisar hingga $42 \mathrm{~m}$ dari tempat asal (Mikoshiba, 1983). Selain melalui bantuan angin, Peronosclerospora juga disinyalir dapat tersebar terbawa melalui benih (White, 2000). Peredaran benih jagung antar daerah diduga berperan dalam penyebaran patogen-patogen penyebab penyakit bulai ini.

Karakteristik konidia Peronosclerospora dipengaruhi oleh keadaan iklim, jenis dan varietas tanaman inang (Telle et al., 2011). Species Peronosclerospora yang sama yang berasal dari 
lokasi yang berbeda akan memberikan reaksi yang berbeda terhadap tanaman inang yang sama. Hal ini ditunjukkan oleh penelitian yang dilakukan oleh Bock et al. (2000). Konidia P. sorghi yang menyerang tanaman sorgum diperoleh dari berbagai lokasi di Afrika. Terdapat perbedaan morfologi antar lokasi baik berupa dimensi konidia maupun konidiofornya. Meskipun demikian patogenisitasnya berbeda dari $P$. sorghi yang satu dengan yang lainnya (Bock et al., 2000). Lebih lanjut lagi Perumal et al. (2008) melaporkan bahwa P. sorghi yang diperoleh dari 14 lokasi menunjukkan keragaman genetik yang berbeda setelah diuji dengan menggunakan teknik AFLP (Amplified Fragment Length Polymorphism). Penggunaan metalaksil sebagai seed treatment mampu menekan serangan sorghum downy mildew (SDW) yang disebabkan oleh $P$. sorghi. Akan tetapi timbulnya ledakan SDW di Texas mengindikasikan bahwa seed treatment dengan metalaksil tidak lagi efektif untuk menekan serangan $P$. sorghi. Hasil analisis AFLP menunjukkan telah munculnya patotipe baru dari $P$. sorghi yang mampu tahan terhadap metalaksil (Perumal et al., 2008). Keadaan yang sama diduga terjadi pula pada penelitian ini.

Tabel 2. Perkecambahan konidia Peronosclerospora spp. asal beberapa dareah di Jawa Barat setelah diuji dengan tiga bahan aktif fungisida.

\begin{tabular}{lccccc}
\hline \multirow{2}{*}{ Perlakuan } & \multicolumn{5}{c}{ Rata-rata persentase perkecambahan (\%) } \\
\cline { 2 - 5 } & SMD & BDG & MJL & GRT & KBB \\
\hline Akuades steril & $15,73 \mathrm{~d}$ & $18,36 \mathrm{c}$ & $23,16 \mathrm{c}$ & $20,60 \mathrm{~b}$ & $42,64 \mathrm{~d}$ \\
Metalaksil & $10,52 \mathrm{c}$ & $2,74 \mathrm{~b}$ & $12,18 \mathrm{~b}$ & $17,96 \mathrm{~b}$ & $13,47 \mathrm{~b}$ \\
Dimetomorf & $0,00 \mathrm{a}$ & $0,00 \mathrm{a}$ & $0,00 \mathrm{a}$ & $0,00 \mathrm{a}$ & $0,47 \mathrm{a}$ \\
Fenamidon & $2,38 \mathrm{~b}$ & $0,00 \mathrm{a}$ & $8,94 \mathrm{~b}$ & $0,00 \mathrm{a}$ & $16,52 \mathrm{c}$ \\
\hline
\end{tabular}

Keterangan: Perbedaan huruf dibelakang angka persentase perkecambahan pada kolom yang sama menunjukkan perbedaan yang signifikan antar perlakuan berdasarkan Uji lanjut Duncan pada taraf nyata 5\%. SMD = Kab. Sumedang, BDG $=$ Kab. Bandung, MJL = Kab. Majalengka, GRT = Kab. Garut dan KBB = Kab. Bandung Barat.

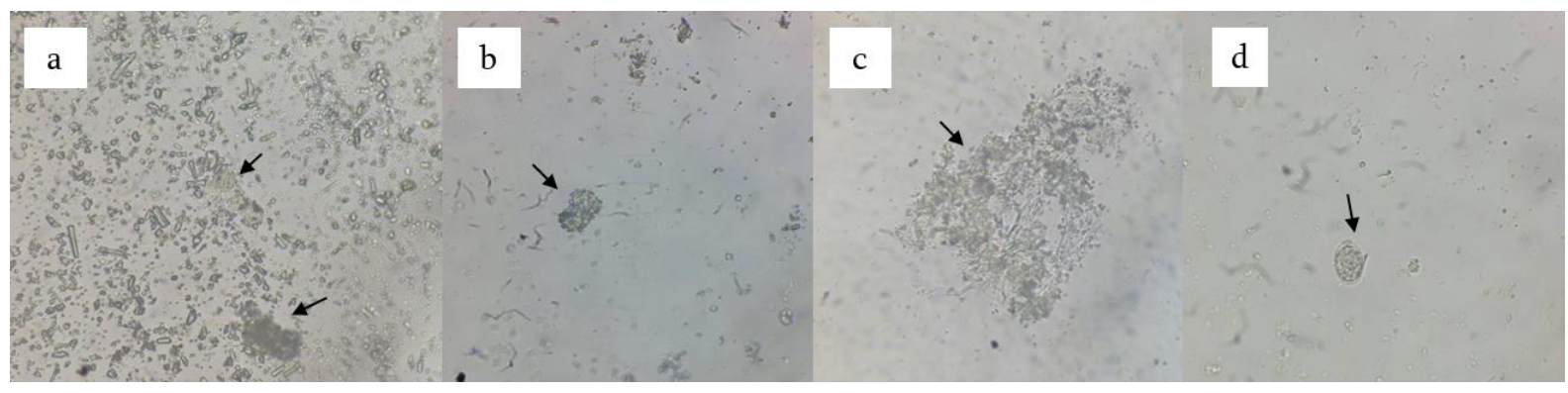

Gambar 1. Konidia Peronosclerospora spp. yang mengalami kerusakan akibat perlakuan fungisida metalaksil (a), dimetomorf (b), fenamidon (c) dan konidia yang berkecambah pada perlakuan fungisida metalaksil (d).

Perkecambahan konidia Peronosclerospora spp. yang dikumpulkan dari beberapa daerah di Jawa Barat menunjukkan indikasi adanya penurunan keefektifan beberapa bahan aktif fungisida (Tabel 2). Secara umum, konidia Peronoscleropsora spp. dapat berkecambah dengan baik pada perlakuan kontrol. Sheridan \& Sheehan (1980) menyatakan bahwa konidia jamur berkecambah lebih baik pada akuades yang diautoclave dibandingkan dengan akuades yang tidak diautoclave. Pada percobaan ini, akuades yang digunakan telah diautoclave sebelumnya sehingga perkecambahan konidia diharapkan lebih baik. Persentase perkecambahan Peronosclerospora spp. juga ditemukan relatif baik ditemukan pada perlakuan metalaksil dibandingkan dengan perlakuan fungisida lain pada hampir semua lokasi pengambilan sampel, kecuali di Kabupaten Bandung 
yang persentase perkecambahannya rendah sekitar $2,74 \%$.

Di Kabupaten Sumedang, hanya fungisida dimetomorf yang masih dapat menghambat perkecambahan konidia Peronosclerospora spp. secara total, terlihat dari tidak adanya konidia yang dapat berkecambah. Demikian pula dengan konidia yang diperoleh di Kabupaten Bandung, Kabupaten Majalengka dan Kabupaten Garut. Sementara fenamidon dapat menghambat perkecambahan konidia Peronoscleropora spp. secara menyeluruh pada isolat asal Kabupaten Bandung dan Kabupaten Garut. Secara umum diantara semua perlakuan fungisida yang diuji, fungisida dimetomorf efektif dalam mengendalikan penyakit bulai dengan menghambat perkecambahan konidia Peronosclerospora spp. Perlakuan fungisida menghambat perkecambahan dengan merusak konidia (Gambar 1). Sementara pada perlakuan fungisia berbahan aktif metalaksil, telah terjadi penurunan keefektifannya. Metalaksil bekerja dengan menghambat sintesis asam nukleat dan sintesis protein, fenamidon bekerja melalui gangguan fungi mitokondria (Gisi \& Sierotzki, 2008), sementara dimetomorf mengganggu perkembangan patogen melalui gangguan pada pembentukan dinding sel (Cohen et al., 1995). Dilaporkan oleh Gisi \& Sieotzki (2008) bahwa fungisida berbahan aktif dari golongan carboxylic acid amides termasuk diantaranya dimetomorf memiliki resiko kemunculan populasi patogen resisten yang relatif rendah, dengan alasan yang belum diketahui dengan jelas.

Fungisida yang mempunyai mekanisme kerja yang spesifik dengan target single-site memicu timbulnya populasi patogen yang resisten relatif lebih cepat dibandingkan dengan fungisida dengan mekanisme kerja multi-site (Hobbelen et al., 2014). Oleh karena itu diperlukan strategi pengelolaan untuk memperpanjang waktu penggunaan fungisida tersebut. Beberapa strategi yang dapat diterapkan antara lain dengan menggabungkan beberapa jenis fungisida yang mempunyai mekanisme kerja yang berbeda menjadi satu, baik sebagai formula maupun tank-mixed. Fungisida campuran tersebut selain memberikan pengendalian penyakit tanaman lebih baik dibandingkan dengan fungisida berbahan aktif tunggal, juga dapat menunda terbetuknya populasi patogen yang resisten terhadap fungisida (Gisi, 1996).

\section{SIMPULAN DAN SARAN}

Patogen penyebab penyakit bulai di beberapa lokasi penanaman jagung di Jawa Barat umumnya disebabkan oleh $P$. maydis, kecuali di Kabupaten Bandung Barat, terdeteksi adanya $P$. sorghi sebagai penyebab penyakit bulai. Penurunan keefektifan fungisida berbahan aktif metalaksil ditemukan di semua lokasi pengambilan sampel (Kabupaten Sumedang, Kabupaten Bandung, Kabupaten Majalengka, Kabupaten Garut dan Kabupaten Bandung Barat. Fenamidon menurun keefektifannya ketika diuji terhadap perkecambahan konidia Peronosclerospora spp. yang berasal dari Kabupaten Sumedang, Kabupaten Majalengka dan Kabupaten Bandung Barat. Sementara dimetomorf masih terlihat efektif mengendalikan penyakit bulai dilihat dari kemampuannya dalam menghambat perkecambahan konidia Peronosclerospora spp. di semua lokasi pengambilan sampel.

\section{DAFTAR PUSTAKA}

Agrios GN, 2005. Plant Pathology. New York: Academic Press.

Aktar MW, D Sengupta,and A Chowdhury. 2009. Impact of pesticides use in agriculture: their benefits and hazards. Interdisciplinary Toxicology 2, 1-12.

Bock CH, MJ Jeger, LK Mughogho, KF Cardwell, E Mtisi, G Kaula, and D Mukansabimana. 2000. Variability of Peronosclerospora sorghi isolates from different geographic locations and hosts in Africa. Mycological Research 104, 61-8.

Burhanuddin. 2009. Fungisida metalaksil tidak efektif menekan penyakit bulai (Peronosclerospora maydis) di Kalimantan Barat dan alternatif pengendaliannya. Prosiding Seminar Nasional Serealia.

Burhanuddin. 2011. Identifikasi cendawan penyebab penyakit bulai di Jawa Timur dan Madura. Suara Perlindungan Tanaman 1, 21-6. 
Cohen Y, A Baider, and BH Cohen. 1995. Dimetomorph activity against oomycete fungal plant pathogen. Phytopathology 85, 1500-6.

Gisi U. 1996. Synergistic interaction of fungicides in mixtures. Phytopathology 86, 1273-9.

Gisi U, and H Sierotzki. 2008. Fungicide modes of action and resistance in downy mildews. European Journal of Plant Pathology 122, 157-67.

Hobbelen PHF, ND Paveley, and F Van Den Bosch. 2014. The emergence of resistance to fungicides. PLoS ONE 9, e91910.

Ishii H. 2006. Impact of fungicide resistance in plant pathogens on crops disease control and agricultural environment. Japan Agricultural Research Quarterly 40, 205-11.

Jatnika, W, AL Abadi, dan LQ Aini. 2013. Pengaruh aplikasi Bacillus sp dan Pseudomonas sp. terhadap perkembangan penyakit bulai yang disebebkan oleh jamur patogen Peronosclerospora maydis pada tanaman jagung. Jurnal HPT. 1 (4): 19-29.

Mcgrath MT. 2001. Fungicide resistance in cucurbit powdery mildew: experiences and challanges. Plant Disease 85, 237-45.

Mcgrath MT. 2004. What are fungicides. The Plant Health Instructor.

Mikoshiba H, 1983. Studies on the control of downy mildew disease of maize in tropical countries of Asia. Ibaraki: T.A.R.C.

Muis A, MB Pabendon, N Nonci, and WPS Waskito. 2012. Keragaman genetik patogen penyebab bulai berbasis marka SSR. Prosiding Seminar Insentif. Riset SINas 2012. Bandung, 29-30 November 2012. pp. 217222.

Perumal R, P Nimmakayala, SR Erattaimuthu, E-G No, UK Reddy, LK Prom, and G Odvody. 2008. Simple sequence repeat markers useful for sorghum downy mildew
(Peronosclerospora sorghi) and related species. BMC Genetics 9.

Rashid Z, PH Zaidi, MT Vinayan, SS Sharma, and TA Srirama Setty. 2013. Downy mildew resistance in maize (Zea mays L.) across Peronosclerospora species in lowland tropical Asia. Crop Protection 43, 183-91.

Rustini US, MS Sinaga, SH Hidayat, and S Wiyono. 2015. Ecological characteristic of Peronosclerospora maydis in Java, Indonesia. International Journal of Sciences: Basic and Applied Research 19, 159-67.

Sahlan, dan ZAM Ahmad. 2003. Isolasi dan identifikasi penyebab penyakit speckle daun pisang. J. Hort. 13 (3): 190-196.

Secor GA, and VV Rivera. 2012. Fungicide resistance assays for fungal plant pathogens. In: Bolton MD, Thomma BPHJ, eds. Plant Fungal Pathogens: Methods and Protocols. Totowa, NJ: Humana Press, 385-92.

Sheridan JJ, and PJ Sheehan. 1980. Some factors affecting the germination. Irish Journal of Agricultural and Food Research 19, 147-54.

Talanca, AH. 2013. Status penyakit bulai pada tanaman jagung dan pengendaliannya. Seminar Nasional Inovasi Teknologi Pertanian. 76-87.

Talanca AH, Burhanuddin, dan A Tenrirawe. 2011. Uji resistensi cendawan (Peronosclerospora maydis) terhadap fungisida Saromil 35 SD (b.a metalaksil). Prosiding Seminar dan Pertemuan Tahunanan XXI PEI-PFI Komda Sulawesi Selatan.

Telle S, R Shivas, M Ryley, and M Thines. 2011. Molecular phylogenetic analysis of Peronosclerospora (Oomycetes) reveals cryptic species and genetically distinct species parasitic to maize. European Journal of Plant Pathology 130, 521-8.

White, DG. 2000. Compendium of corn disease. (3 $3^{\text {nd }}$ ed). Minnesota (AS): APS Pr. 